\title{
A validated stability indicating HPLC method for the determination of process-related impurities in pantoprazole bulk drug and formulations
}

\author{
Saurabh Pandey1,,*, Preeti Pandey ${ }^{1}$, Durgesh Mishra ${ }^{2}$, Umesh Kumar Singh ${ }^{3}$ \\ ${ }^{1}$ Pranveers Singh Institute of Technology, ${ }^{2}$ Dr. K.N.Modi Institute of Pharmaceutical Education and Research, ${ }^{3}$ Kharvel \\ Shubharti College of Pharmacy, Shubharti University, India
}

\begin{abstract}
A stability-indicating high-performance liquid chromatographic (HPLC) method was developed with short run time and validated for the assay of process related impurities of pantoprazole in bulk form. Resolution of drug, its potential impurities and degradation products were achieved on a Hypersil ODS column utilizing a gradient with $0.01 \mathrm{M}$ phosphate buffer of $\mathrm{pH} 7$ and acetonitrile as eluent, at the detection wavelength of $290 \mathrm{~nm}$. Flow rate was set at $1 \mathrm{~mL} \mathrm{~min}^{-1}$. The procedure was found to be specific, linear $(\mathrm{r}=0.999)$, recovery $(97.9-103 \%), \mathrm{LOD}\left(0.043-0.047 \mu \mathrm{gmL}^{-1}\right), \mathrm{LOQ}\left(0.13-0.14 \mu \mathrm{gmL}^{-1}\right)$ and robust. Acceptable robustness indicates that the assay method remains unaffected by small but deliberate variations. Pantoprazole was found to degrade in acidic, oxidative and under photolytic stress conditions. The drug was stable to alkaline and dry heat conditions. This method has been successively applied to pharmaceutical formulation and no interference from the excipients was found.
\end{abstract}

Uniterms: High performance liquid chromatography/qualitative analysis. High performance liquid chromatography/method development. Pantoprazole/forced degradation.

\begin{abstract}
Desenvolveu-se método indicador de estabilidade por Cromatografia a Líquido de Alta Eficiência (CLAE) com pequeno tempo de corrida e validado para o ensaio de impurezas relacionadas ao processo de produção de pantoprazol em batelada. A determinação do fármaco, de suas impurezas potenciais e dos produtos de degradação foi realizada com coluna de ODS Hypersil, utilizando gradiente com tampão de fosfato $0,01 \mathrm{M} \mathrm{pH} 7$ e acetonitrila como eluente, no comprimento de onda de deteç̧ão de $290 \mathrm{~nm}$. A velocidade de fluxo foi fixada em $1 \mathrm{mLmin}^{-1}$. O procedimento se mostrou específico, linear $(\mathrm{r}=0,999)$, com recuperação $(97,9-103 \%), \operatorname{LOD}\left(0,043-0,047 \mu \mathrm{gmL}^{-1}\right)$, LOQ $\left(0,13-0,14 \mu \mathrm{g} \mathrm{mL}^{-1}\right)$ e robusto. Robustez aceitável indica que o método de ensaio não é afetado por variações pequenas, exceto as planejadas. $\mathrm{O}$ pantoprazole degradou em condições ácidas, oxidativas e sob condições de estresse fotolítico. $\mathrm{O}$ fármaco foi estável em condições alcalinas e de calor seco. Este método tem sido sucessivamente aplicado à formulação farmacêutica e não se encontrou interferência de excipientes.
\end{abstract}

Unitermos: Cromatografia Líquido de Alta Eficiência/análise qualitativa. Cromatografia Líquido de Alta Eficiência/desenvolvimento de método. Pantoprazol/degradação forçada.

\section{INTRODUCTION}

[(Pyridylmethyl)sulfinyl]benzimidazoles (PSBs) have proved to be highly active inhibitors of the gastric $(\mathrm{H}+, \mathrm{K}+)$-ATPase both in vitro and in vivo with high and long lasting antisecretory activity (Wallmark et al.,1985; Larsson et al.,1983). Pantoprazole (PNT), 5-(difluo-

*Correspondence: Saurabh Pandey. Pranveer Singh Institute of Technology, 09795459608, Kanpur, U.P., India. E-mail: 23.pandey@gmail.com romethoxy)-2-[[(3,4- dimethoxy-2-pyridinyl)methyl] sulfinyl]-1H-benzimidazole is an oral pharmaceutically active compound having promising anti-ulcer activity (Kohl et al., 1992) and belongs to the class of 2-[[(2pyridyl) methyl]sulfinyl]- $1 H$-benzimidazoles. In general these classes of compounds were used for the prevention and treatment of gastric acid related diseases (Kohl et al., 1988). Literature studies reveal different methods for the preparation of PNT (Kormer et al., 1990).

Numerous methods have been developed for the 
determination of PNT in the bulk drug substance or dosage forms, either alone or in the presence of other drugs. Techniques used for its assay include spectrophotometry (Moustafa et al., 2000; Wahbi et al., 2002; Rajic et al., 2003; Salama et al., 2003; Rahman et al., 2005, 2006), polarography (Radi, 2003; Radi et al., 2003), thermogravimetry (Reddy et al., 2007), amperometry (Castro et al., 2005), HPLC (Mansour et al., 2000; Storms et al., 2002; Sivkumar et al., 2007, 2008; Margues et al., 2007; Patel et al., 2007; Zeinab et al., 2006), GC method (Nanduri et al., 2008), TLC (Agbaba et al., 2004; Gosavi et al. 2006), and capillary electrophoresis (Tivesten et al., 1999).

The presence of impurities in an active pharmaceutical ingredient (API) can have a significant impact on the quality and safety of the drug products. The regulatory framework basically addresses the development of analytical approaches focused on the impurities contained in the drugs. The requirements for testing the impurities become increasingly more complex due to the fact that the sources of potential impurities are numerous, including diverse synthetic routes, possible side reactions, degradation reactions affected by different storage conditions, different package materials, etc.

PNT is synthesized by condensation of 5-(difluoromethoxy)-2-mercapto-1 $H$-benzimidazole (I) and 2-(chloromethyl)-3,4-dimethoxypiridine hydrochloride in the presence of an inorganic base, to yield 5-(difluoromethoxy)-2-[[(3,4-dimethoxy-2-pyridinyl) methyl] thio-1H-benzimidazole (II), which - upon further oxidation with a suitable oxidizing agent eventually leads to pantoprazole. The route of synthesis and Chemical structures of the possible impurities contained in PNT are shown in Figure 1. The most important and critical step is PNT oxidation. Consequently, as a potential byproduct the sulfone, i.e., 5-(difluoromethoxy)-2-[[(3,4-dimethoxy2-pyridinyl) methyl] sulfonyl-1 $H$-benzimidazole (III), could appear via a structurally labile overoxidated sulfoxide (Mathad et al., 2004).

Forced degradation studies of new drug substances and drug products are essential to help develop and demonstrate specificity of stability-indicating methods and to determine the degradation pathways and degradation products of the active ingredients. Procedures for the preparation of specific degradation products needed for method validation often emerge from these studies (Dan et al., 2002).

Developing a short run time stability-indicating HPLC method for PNT is very challenging because there are many PNT related compounds which have similar structures as PNT. In this paper, we report the shorter analysis time (in comparison to European Pharmacopoeia, 2008; Jelena et al., 2010; Jing-yi et al., 2010) stability- indicating HPLC method for the estimation of PNT and its related substances in the presence of degraded impurities, employed by forced degradation method.

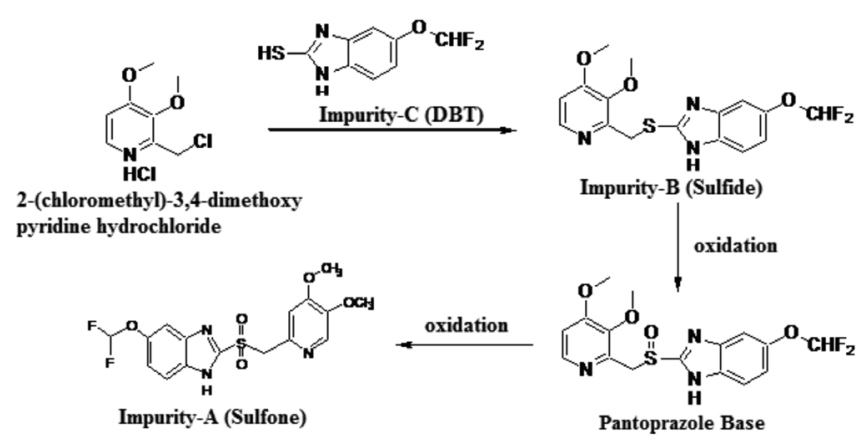

FIGURE 1 - Synthesis scheme of pantoprazole Sodium.

\section{MATERIAL AND METHODS}

\section{Material}

Used Chemicals were obtained from the following suppliers: Dipotassium hydrogen phosphate, disodium hydrogen phosphate, orthophosphoric acid, sodium hydroxide, hydrochloric acid, hydrogen peroxide $(30 \% \mathrm{w} / \mathrm{v})$ from Qualigens, Mumbai, India and Acetonitrile (ACN) HPLC grade (S.D. fine Chemicals, Mumbai, India). PNT, Impurity A/ 5-(difluoromethoxy)-2-\{[(4,5-dimethoxypyridin-2-yl)methyl]sulfonyl $\}$-1 $H$-benzimidazole (Sulfone), Impurity-B/ 5-(difluoromethoxy)-2-\{[(4,5-dimethoxypyridin-2-yl)methyl]sulfanyl $\}-1 H$-benzimidazole (Sulfide), Impurity-C/ 5-(difluoromethoxy)-1H-benzimidazole2-thiol (DBT) was obtained from Laurel Pharma, Bangalore. The PNT formulations i.e. Pantosec 40 (tablet), Allpan 40 (tablet), Altopan- i.v. (injection) are procured from local drug stores. The deionized water (Mili Q, In house) was used throughout.

\section{Methods}

\section{Instrumentation}

A HPLC (Shimadzu, Class VP HPLC, Japan) equipped with Dual Wavelength absorbance detector, $\mathrm{pH}$ Meter (744 from Metrohm), Analytical Balance (XS 205 from Mettler Toledo), Ultrasonic Bath (RX106 SONOREX), Photostability Chamber (Thermo lab), autopippette (100 - $1000 \mu \mathrm{L}$ from Eppendorf), Oven (VA1,VA3 from SHEL LAB) were used.

\section{Chromatographic conditions}

Gradient elution of mobile phase comprising of Acetonitrile and $0.01 \mathrm{M}$ phosphate buffer ( $\mathrm{pH}$ of 7 adjusted 
with orthophosphoric acid) with flow rate of $1 \mathrm{~mL} \mathrm{~min}^{-1}$ was performed on Hypersil ODS $(125 \times 4.0 \mathrm{~mm}, 5 \mu \mathrm{m})$. The column temperature was maintained at $40{ }^{\circ} \mathrm{C}$ and the injection volume was $20 \mu \mathrm{L}$. Prior to injection of analyte, the column was equilibrated for 30-40 min with mobile phase. The eluents were monitored at $290 \mathrm{~nm}$, data were acquired, stored and analysed with Class VP Chromatographic Software.

\section{Preparation of stock and system suitability solution}

All samples and standards were diluted using HPLC grade $\mathrm{ACN}$ and $0.1 \mathrm{M}$ Sodium hydroxide in the ratio of 50:50 (v/v). Separate stock Solutions were prepared by dissolving appropriate amounts of PNT and related impurities by sonication followed by filling to the volume with the same diluent.

A stock solution was prepared for PNT $\left(460 \mu \mathrm{g} \mathrm{mL}^{-1}\right)$ and each impurity $(\mathrm{A}, \mathrm{B}, \mathrm{C})$ having final concentration of $440 \mu \mathrm{g} \mathrm{mL}^{-1}$. Equal volume $(2 \mathrm{~mL})$ of impurity B \& impurity $\mathrm{C}$ was mixed from their stock solutions and further diluted to $100 \mathrm{~mL}$ with diluent labeled as stock A. For preparation of stock B, $2 \mathrm{~mL}$ of PNT \& impurity A was mixed from their stock solutions and diluted to $100 \mathrm{~mL}$ by same diluent. The stock A \& B was used further in validation studies. System suitability solution was prepared by adding $1 \mathrm{~mL}$ of sulphone impurity (of concentration $46 \mu \mathrm{g} \mathrm{mL}^{-1}$ ) into $23 \mathrm{mg}$ of PNT and volume was made upto $50 \mathrm{~mL}$ by using diluents.

\section{Sample solution}

Ten tablets (Pantosec40 and Allpan 40) were weighed individualy and then powdered. Powder aliquot equivalent to $46 \mathrm{mg}$ pure pantoprazole was accurately weighed and transferred to a $100 \mathrm{~mL}$ volumetric flask. For Injection vial (Altopan- i.v.) containing $46 \mathrm{mg}$ pure PNT was dissolved in diluent and after sonication for 10 min volume was made upto $100 \mathrm{~mL}$ in volumetric flask.

\section{Forced degradation of Pentaprazole API}

In order to establish whether the analytical method and the assay were stability indicating, the PNT was stressed under various conditions to promote degradation. $23 \mathrm{mg}$ PNT was allowed to hydrolyze in base $(0.1 \mathrm{~N}$ $\mathrm{NaOH})$, acid $(0.05 \mathrm{~N} \mathrm{HCl})$ and hydrogen peroxide $(0.01 \%)$ separately for 2 minutes. Further the acid degraded solution was neutralized by adding $5 \mathrm{~mL}$ of $0.05 \mathrm{M}$ sodium hydroxide and alkaline degraded solution was neutralized by adding $5 \mathrm{~mL}$ of $1 \mathrm{~N}$ hydrochloric acid. The volume of all three samples was made up with diluent upto $50 \mathrm{~mL}$. PNT was also studied for its thermal degradation at $80{ }^{\circ} \mathrm{C}$ for $1 \mathrm{~h}$ respectively. For photolytic degradation $500 \mathrm{mg}$ of PNT was transferred into two separate loss on drying (LOD) bottle each. One LOD bottle was covered with lid and then with aluminium foil (dark control) and another LOD bottle (photolytic exposed sample) was placed as such into the photolytic chamber by covering with lid in such a way to get the minimum exposure of 2600 lux of uv light for 100 hours. $23 \mathrm{mg}$ of dark control sample and photolytic exposed sample was weighed and diluted each to $50 \mathrm{~mL}$ volume with the diluent. Single injection of blank and PNT solution was injected of all degradation conditions. The peak purity and \% degradation of PNT peak in all the degradation conditions was checked by using following formula:

$$
\% \text { Degradation }=\frac{\begin{array}{c}
\% \text { Purity in } \\
\text { control sample }
\end{array}-\begin{array}{c}
\% \text { Purity in } \\
\text { degradation sample }
\end{array}}{\% \text { Purity in control sample }} \times 100
$$

\section{Method validation}

The method validation was done by evaluating specificity, detection limit (LOD) and quantitation limit (LOQ), linearity, accuracy, repeatability and reproducebility, robustness and system suitability of PNT with impurities in accordance with ICH guidelines (ICH, 2005). The system suitability study was performed before each validation study.

\section{Specificity}

Specificity is the ability to assess unequivocally the analyte in the presence of components, which may be expected to be present. The specificity of the method was demonstrated by injecting each process-related impurity spiked with PNT. For specifity, the PNT sample was spiked with impurities by using stock solution A and B.

\section{System suitability}

System suitability test was performed to evaluate the chromatographic parameters (capacity factor, number of theoretical plates, asymmetry of the peaks and resolution between two consecutive peaks) before each validation run. The system suitability criterion is resolution between PNT and impurity sulfone peaks.

\section{Linearity}

The linearity of an analytical procedure is its ability to obtain test results, which are directly proportional to the concentration of the analyte in the sample. The linearity of response was determined in triplicate for all three impurities and PNT in the range from 0.1 to $2 \mu \mathrm{g} \mathrm{mL}^{-1}$. The dilutions were prepared by using impurity stock solution A \& B. Response factor for all known impurities against Pantoprazole was calculated from the following formula: 


$$
\text { Response factor }=\frac{\text { Slope of pantoprazole }}{\text { Slope of individual impurity }}
$$

\section{Limit of detection and quantification}

The limit of detection (LOD) of a compound is defined as the lowest concentration that can be detected. The limit of quantification (LOQ) is the lowest concentration of a compound that can be quantified with acceptable precision and accuracy. For each impurity and PNT the linearity data was used to determine residual standard deviation $(\sigma)$ and slope (S). The LOD and LOQ were calculated from the data using formula $3 \sigma / \mathrm{S}$ and $10 \sigma / \mathrm{S}$ respectively.

\section{Accuracy}

The accuracy of an analytical procedure expresses the closeness of agreement between the value, which is accepted either as a conventional true value or an accepted reference value and the value found. The recovery, evaluated with the standard addition procedure at three concentrations in triplicate at QL level, $100 \%$ and $200 \%$ of target limit.

\section{Precision (repeatability and reproducibility)}

The precision of an analytical procedure expresses the closeness of agreement between a series of measurements from multiple sampling of the same homogeneous sample under prescribed conditions. Precision maybe considered as a repeatability and reproducibility.

Repeatability expresses the precision under the same operating conditions over a short interval of time. Repeatability of the method was studied by spiking impurities with PNT at $100 \%$ specification level. The precision was examined by analyzing six replicates and the percentage relative standard deviation was calculated for the area and retention time of all the impurities and PNT to demonstrate repeatability. Reproducebility of the method was studied by spiking impurities with PNT at $100 \%$ specification level on different day.

Reproducibility is normally expressed as the lack of the influence on the test results of operational and environmental variables of the analytical method. In order to demonstrate reproducibility of the method the precision experiment was repeated by using different laboratory, different instrument, and different column on another day. The percentage bias of result was calculated between original condition and changed condition.

\section{Robustness}

The robustness of an analytical procedure is the measure of its capacity to remain unaffected by small, but deliberate, variations in method parameters and provides an indication of its reliability during normal usage. The HPLC parameters were deliberately varied from normal procedural conditions including detector wavelength ( $\pm 5 \mathrm{~nm}$ ), column oven temperature $\left( \pm 5^{\circ} \mathrm{C}\right)$, the flow rate $( \pm 10 \%), \mathrm{pH}$ of buffer solution $( \pm 0.2)$, gradient program $( \pm 2 \%)$ to test the robustness of the method.

\section{Solution stability}

Chromatographic analyses typically are performed by using autosamplers and overnight runs. As such, it is important to verify that the sample is stable in the solution prescribed by the method for periods encompassing the expected analysis duration period. Stability of test solution at analyte concentration was studied by keeping the solution in tightly capped volumetric flask at room temperature on a laboratory bench for $24 \mathrm{~h}$. The purity of the test solution was checked for by calculating $\%$ difference in peak area for PNT peak in standard and sample solution was calculated upto $24 \mathrm{~h}$ interval.

\section{RESULT AND DISCUSSION}

\section{Development and optimization of the HPLC method}

Proper selection of the method depends upon the nature of the sample (ionic or ionisable or neutral molecule) its molecular weight and solubility. PNT and their related impurities dissolve in polar solvents thus RP-HPLC was selected to estimate them. To develop a rugged and suitable stability indicating HPLC method for the quantitative determination of PNT and their impurities, the chromatographic conditions were selected after testing the different parameters such as columns, diluents, buffer, buffer concentration, organic solvent for mobile phase and mobile phase composition, gradient condition, column temperature and other chromatographic conditions.

UV spectra of all the compounds were studied by scanning them between $190 \mathrm{~nm}$ to $400 \mathrm{~nm}$. The wavelength maximum of PNT was found to be $204 \mathrm{~nm}$ and $302 \mathrm{~nm}$. Since UV cut-off commonly uses solvent is up to $210 \mathrm{~nm}$, therefore wavelength maximum that could be taken into consideration is between $280-310 \mathrm{~nm}$. The $\lambda_{\max }$ of most of the impurity lies near to $290 \mathrm{~nm}$. During the experiments, it has been observed that baseline stability, mobile phase interference and noise level were more desirable at $290 \mathrm{~nm}$ than $302 \mathrm{~nm}$. Moreover, the adequate detection and quantification limit were found for all the impurities and PNT at $290 \mathrm{~nm}$ therefore, $290 \mathrm{~nm}$ was finalized as common wavelength for detection. 
TABLE I - HPLC method development and optimization trials

\begin{tabular}{|c|c|c|c|c|c|c|c|c|c|c|c|c|c|c|c|c|c|c|c|c|c|c|}
\hline Trials & & & 2 & & & 3 & \multicolumn{6}{|c|}{4} & \multicolumn{6}{|c|}{5} & \multicolumn{4}{|c|}{6} \\
\hline Mobile Phase & \multicolumn{2}{|c|}{$\begin{array}{c}\text { pH-7.0 NHP } \\
\text { (with TEA), } \\
\text { A. Water: } \\
\text { ACN::50:50 }\end{array}$} & \multicolumn{2}{|c|}{$\begin{array}{c}0.01 \mathrm{M} \mathrm{NHP} \\
\mathrm{pH}-7.0 \\
\text { (with OPA), } \\
\text { A. Buffer: } \\
\text { ACN:: 50:50 }\end{array}$} & \multicolumn{2}{|c|}{$\begin{array}{c}0.01 \text { M NHP } \\
\text { pH-7.6 } \\
\text { (with OPA), } \\
\text { A. Buffer: } \\
\text { ACN::70:30 }\end{array}$} & \multicolumn{6}{|c|}{$\begin{array}{c}0.01 \text { M KHP, pH-7.6 (with OPA), } \\
\text { A. Buffer: ACN::80:20 } \\
\text { B. ACN: Buffer:: } 30: 70\end{array}$} & \multicolumn{6}{|c|}{$\begin{array}{l}0.01 \text { M KHP, pH-7 (with OPA), } \\
\text { A. Buffer: ACN::80:20 } \\
\text { B. ACN: Buffer:: } 30: 70\end{array}$} & \multicolumn{4}{|c|}{$\begin{array}{c}\text { 0.01 M KHP, } \\
\text { pH-7 (with OPA). } \\
\text { A. Buffer: } 100, \\
\text { B. ACN: } 100\end{array}$} \\
\hline \multirow{3}{*}{$\begin{array}{lc}\text { Gradient } & (\mathrm{min}) \\
\text { condition } & \% \mathrm{MP}-\mathrm{A} \\
& \% \mathrm{MP}-\mathrm{B}\end{array}$} & 0.01 & 15 & 0.01 & 15 & 0.01 & 15 & 0.01 & 05 & 10 & 15 & 20 & 25 & 0.01 & 05 & 10 & 15 & 20 & 25 & 0.01 & 10 & 15 & 20 \\
\hline & 100 & 100 & 100 & 100 & 100 & 100 & 80 & 80 & 55 & 55 & 80 & 80 & 90 & 90 & 55 & 55 & 90 & 90 & 80 & 20 & 80 & 80 \\
\hline & & L & $\mathrm{N}$ & & & IL & 20 & 20 & 45 & 45 & 20 & 20 & 10 & 10 & 45 & 45 & 10 & 10 & 20 & 80 & 20 & 20 \\
\hline Gradient curve & \multicolumn{2}{|c|}{ Linear } & \multicolumn{2}{|c|}{ Linear } & \multicolumn{2}{|c|}{ Linear } & \multicolumn{6}{|c|}{ Linear } & \multicolumn{6}{|c|}{ Linear } & \multicolumn{4}{|c|}{ Linear } \\
\hline Column & \multicolumn{2}{|c|}{$\begin{array}{l}\text { Phenomenex } \\
\text { Luna C8 } \\
(150 \times 4.6) \\
\mathrm{mm}, 5 \mu \mathrm{m}\end{array}$} & \multicolumn{2}{|c|}{$\begin{array}{c}\text { Zorbax } \\
\text { SB C8 } \\
(150 \mathrm{x} 4.6) \\
\mathrm{mm}, 5 \mu \mathrm{m}\end{array}$} & \multicolumn{2}{|c|}{$\begin{array}{c}\text { Zorbax } \\
\text { SB C8 } \\
(150 \mathrm{x} 4.6) \\
\mathrm{mm}, 5 \mu \mathrm{m}\end{array}$} & \multicolumn{6}{|c|}{$\begin{array}{c}\text { Hypersil ODS } \\
(125 \times 4.0) \mathrm{mm}, 5 \mu \mathrm{m}\end{array}$} & \multicolumn{6}{|c|}{$\begin{array}{c}\text { Hypersil ODS } \\
(125 \times 4.0) \mathrm{mm}, 5 \mu \mathrm{m}\end{array}$} & \multicolumn{4}{|c|}{$\begin{array}{c}\text { Hypersil ODS } \\
(125 \times 4.0) \mathrm{mm}, 5 \mu \mathrm{m}\end{array}$} \\
\hline Diluent & \multicolumn{2}{|c|}{ MP-A } & \multicolumn{2}{|c|}{ MP-A } & \multicolumn{2}{|c|}{ MP-A } & \multicolumn{6}{|c|}{ MP-A } & \multicolumn{6}{|c|}{ MP-A } & \multicolumn{4}{|c|}{$\begin{array}{c}\text { MP-A:0.1M } \\
\mathrm{NaOH}:: 50: 50\end{array}$} \\
\hline $\begin{array}{l}\text { Temp. \& } \\
\text { wavelength }\end{array}$ & & $\begin{array}{l}\mathrm{C} \& \\
\mathrm{~nm}\end{array}$ & $\begin{array}{l}25^{\circ} \\
290\end{array}$ & $\begin{array}{l}\mathrm{C} \& \\
\mathrm{~nm}\end{array}$ & & $\begin{array}{l}\mathrm{C} \& \\
\mathrm{~nm}\end{array}$ & & & $0^{\circ} \mathrm{C} \&$ & $290 \mathrm{r}$ & & & & & ${ }^{\circ} \mathrm{C} \&$ & $0 \mathrm{n}$ & & & & $\overline{0}{ }^{\circ} \mathrm{C} \&$ & $290 \mathrm{nn}$ & \\
\hline
\end{tabular}

Observations and corrections to next trial

Trial No. 1 Base line is good but the retention of the sample in the column was too much, fronting, no resolution between the peaks, buffer should be used within $10 \mathrm{mM}$ to $50 \mathrm{mM}$ with slightly basic $\mathrm{pH}$ within the range of Pka value to elute the sample early, stable bond column is needed.

Trial No. 2 Column was changed to stable bonded C8, reduction in fronting, base line is good, no peak resolution, buffer used to stabilize the pH, peak elution is too early.

Trial No. 3 Base line is good, resolution between the sulfone and PNT peak is more than 2 but no peak resolution to others.

Trial No. 4 Baseline is good, column was changed to stable bonded $\mathrm{C} 18$, gradient flow is used to increase the resolution between the peaks but still no resolution between DBT and Sulfone.

Trial No. 5 Base line is good, peak resolution between DBT and Sulfone \& PNT and sulfide are not good, gradient should be changed.

Trial No. $6 \quad$ No interference of any peak with the main peak and to each other, resolution between the sulfone and Pantoprazole peak is more than 2.

MP- Percentage mobile phase, NHP- Disodium hydrogen phosphate, KHP- Disodium hydrogen phosphate, OPA - Orthophosphoric acid, ACN- HPLC grade acetonitrile, TEA- triethylamine.

Our preliminary trials using different columns (Phenomenex Luna C8, Zorbax SB C8), different mobile phases consisting of water-acetonitrile and sodium phosphate buffer- acetonitrile using isocratic elution did not give good peak shape and resolution. For the impurities and PNT, retention times were found near dead point. Therefore, in such case gradient elution is preffered over isocratic. To obtain efficient gradient elution pattern, small linear gradient was employed for development. Several, permutations and combination of ACN-buffer and bufferACN with varying ${ }_{\mathrm{p}} \mathrm{H}$ have been scanned to finalize the components of mobile phase. It has been observed that ACN (mobile phase-A) and phosphate buffer adjusted to pH 7.0 with orthophosphoric acid (mobile phase-B) with gradient elution provide best peak shape and resolution. The diluent preffered is $0.1 \mathrm{M}$ sodium hydroxide: $\mathrm{ACN}$ (50:50). Hypersil ODS a C18 column is preferred over $\mathrm{C} 8$ column because of its hydrophobicity so that to rec- tify retention problems. Table I includes all the trials for optimization of method.

\section{Forced degradation studies}

In forced degradation method pantoprazole sodium was found to degrade substantially under acidic, oxidative conditions while stable under alkaline, thermal condition and under photolytic conditions was miniscule (Table II). The major impurity under acidic and oxidative condition was Sulfide (RRT 1.63) and Sulfone (RRT 0.80) respectively (Figure 2).

\section{Method validation}

PNT and its related impurities were well resolved with no interference from the blank and mobile phase. For all compounds the purity angle was found to be less than 

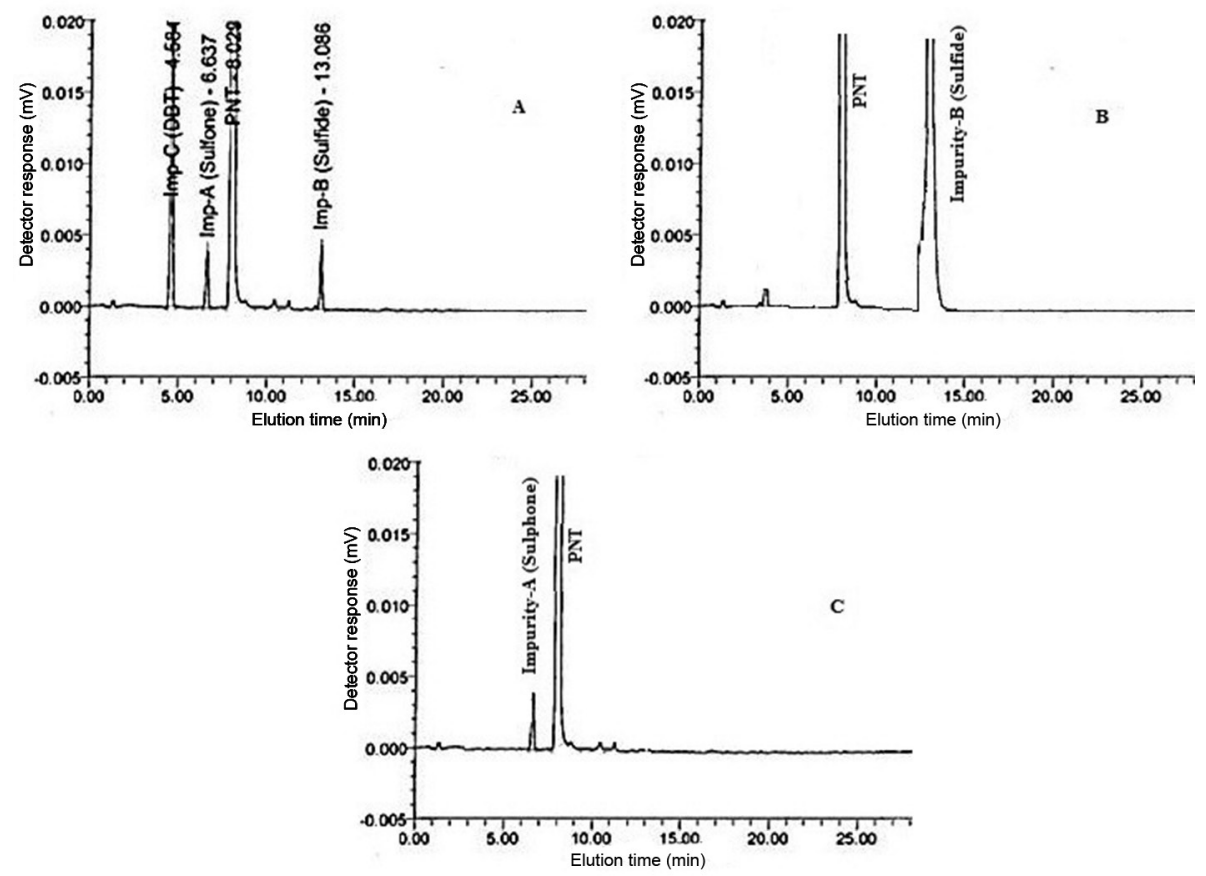

FIGURE 2- Typical chromatogram for A) PNT with impurities; B) Under acidic condition and C) Under oxidative condition.

TABLE II - Results of specificity and purity data

\begin{tabular}{lccc}
\hline Name & $\begin{array}{c}\text { Relative } \\
\text { Retention time }\end{array}$ & $\begin{array}{c}\text { Peak } \\
\text { purity }\end{array}$ & $\begin{array}{c}\text { Purity } \\
\text { threshold }\end{array}$ \\
\hline Pantoprazole & 1.00 & 0.957 & 4.685 \\
Impurity-A & 0.80 & 3.984 & 7.596 \\
Impurity-B & 1.66 & 9.961 & 18.879 \\
Impurity-C & 0.57 & 2.331 & 4.355 \\
\hline
\end{tabular}

purity threshold value. The value of relative retention time and purity data is listed in table II. The described method is linear in the range of $0.1 \mu \mathrm{g} \mathrm{mL}^{-1}$ to $2 \mu \mathrm{g} \mathrm{mL}^{-1}$ of each impurity, demonstrated acceptability of the method for the quantitative determination in that range. The relative response factor (RRF) of Impurity-A, Impurity-B, Impurity-C with respect to PNT was found to be 1.13 , 0.93 and 0.59 respectively. The value of linearity range, equation, corellation coefficient, LOD and LOQ for PNT and its related impurity are shown in Table III.

In the precision study, the percentage relative standard deviation (RSD) of six replicates was found less than $0.13 \%$ for retention time and $1.12 \%$ for peak area of all the impurities and PNT, indicating good repeatability of the method. The results of the reproducibility study under a different set of conditions are also in the same order of magnitude. The percentage bias between two different sets of conditions for retention time and peak area was within \pm 1.29 and \pm 0.29 respectively for all the impurities and PNT, indicates that method is rugged for its intended use. The method showed excellent recovery (accuracy) at three different studied concentrations QL, 100 and $200 \%$ of specification level for all the impurities. The mean recoveries of all the impurities and PNT were found to be in the acceptable range of 97.94 to $102.6 \%$. Table IV shows all the data related to accuracy and precision.

TABLE III - Linearity, LOD and LOQ results for PNT and related impurities

\begin{tabular}{|c|c|c|c|c|c|}
\hline \multirow[b]{2}{*}{ Compound } & \multicolumn{4}{|c|}{ Linearity } & \multirow{2}{*}{$\begin{array}{l}\text { LOD \& LOQ } \\
\quad\left(\mu \mathrm{g} \mathrm{mL} L^{-1}\right)\end{array}$} \\
\hline & Equation & $\begin{array}{c}\text { Range } \\
\left(\mu \mathrm{g} \mathrm{mL}^{-1}\right)\end{array}$ & $\begin{array}{c}\text { Correlation } \\
\text { coefficient }\end{array}$ & $\begin{array}{c}\text { Response } \\
\text { Factor }\end{array}$ & \\
\hline PNT & $Y=46517 x-496$ & $0.13-2$ & 0.9994 & 1 & $0.043 \& 0.129$ \\
\hline Impurity A & $\mathrm{Y}=41112 \mathrm{x}+422$ & $0.14-2$ & 0.9997 & 1.13 & $0.046 \& 0.138$ \\
\hline Impurity B & $Y=49906 x+328$ & $0.14-2$ & 0.9991 & 0.93 & $0.047 \& 0.140$ \\
\hline Impurity C & $Y=78900 x-1399$ & $0.13-2$ & 0.9996 & 0.59 & $0.045 \& 0.134$ \\
\hline
\end{tabular}


TABLE IV - Precision and Accuracy data

\begin{tabular}{|c|c|c|c|c|c|c|c|c|c|c|}
\hline \multirow{2}{*}{ Compound - } & \multicolumn{2}{|c|}{ ART (Min) } & \multirow{2}{*}{$\begin{array}{c}\% \text { RSD } \\
(n=6)\end{array}$} & \multirow{2}{*}{$\%$ Bias } & \multicolumn{2}{|c|}{ APA } & \multirow{2}{*}{$\begin{array}{c}\% \text { RSD } \\
(\mathrm{n}=6)\end{array}$} & \multirow{2}{*}{$\%$ Bias } & \multirow{2}{*}{$\begin{array}{c}\text { Average } \\
\text { Accuracy } \pm \mathrm{SD}\end{array}$} & \multirow{2}{*}{$\%$ RSD } \\
\hline & $\mathrm{OC}$ & $\mathrm{DC}$ & & & $\mathrm{OC}$ & $\mathrm{DC}$ & & & & \\
\hline$\overline{\mathrm{PNT}}$ & 8.11 & 8.12 & 0.11 & 0.12 & 18480516.73 & 18480519.12 & 1.09 & 0.00 & $102.6 \pm 0.81$ & 0.81 \\
\hline Impurity-A & 6.63 & 6.61 & 0.13 & 0.30 & 57466 & 57482.42 & 0.89 & 0.03 & $101.64 \pm 2.3$ & 1.10 \\
\hline Impurity-B & 13.15 & 13.32 & 0.7 & 1.29 & 25339.79 & 25414.21 & 0.91 & 0.29 & $103 \pm 1.93$ & 1.88 \\
\hline Impurity-C & 4.62 & 4.58 & 0.09 & 0.87 & 36404.28 & 36492.18 & 1.12 & 0.24 & $97.94 \pm 1.91$ & 1.96 \\
\hline
\end{tabular}

ART- Average retention time, APA- Average peak area, OC-Original condition, DC-Different condition

Under robustness study, all analytes were adequately resolved. The LOQ solution maintained a signal-to-noise ratio over 10 in all varied conditions. The acceptance criterion for system suitability and relative retention times of all known impurities were checked for each of the following variable chromatographic conditions and passed. The peak resolution between PNT and sulfone impuritiy were all larger than 3 under each variation. The results are shown in table V. No significant change in the process related impurity and PNT was observed during solution stability experiments and all the test solution was found to be stable for at least $24 \mathrm{~h}$.

The method is used to assay the commercial dosage forms that contain PNT. Satisfactory results were obtained and in a good agreement with the labeled amount (Table VI).

The proposed method has shorter retention time for pantoprazole (8.01 versus $11 \mathrm{~min}$ ) and significantly higher resolution factors for all of the resolved compounds as compared with the official European pharmacopoeia procedure (European Pharmacopoeia, 2008). Also the overall elution time is almost less than EP procedure and Letica et al. method (Jelena et al., 2010), about $15 \mathrm{~min}$. The detection and quantization limits are camparable to Letica et al. The proposed method could be used for the fast assay of pantoprazole and its impurities in the bulk drug substance, or in its dosage forms.

TABLE V - Robustness data

\begin{tabular}{lccccc}
\hline Robustness Parameter & \multicolumn{3}{c}{ Relative retention Time } & Resolution & \% RSD $(\mathrm{n}=6)$ \\
\cline { 2 - 4 } & Impurity-A & Impurity-B & Impurity-C & & \\
\hline Control & 0.80 & 1.66 & 0.57 & 4.92 & 2.30 \\
Flow rate $(-10 \%)$ & 0.80 & 1.60 & 0.59 & 4.25 & 0.23 \\
Flow rate $(+10 \%)$ & 0.79 & 1.65 & 0.56 & 4.36 & 1.21 \\
Column Oven Temp. $\left(-5^{\circ} \mathrm{C}\right)$ & 0.80 & 1.64 & 0.61 & 4.94 & 0.82 \\
Column Oven Temp. $\left(+5{ }^{\circ} \mathrm{C}\right)$ & 0.75 & 1.64 & 0.57 & 4.96 & 1.22 \\
pH Change $(-0.2 \mathrm{pH}$ units $)$ & 0.84 & 1.59 & 0.59 & 4.72 & 2.89 \\
pH Change $(+0.2 \mathrm{pH}$ units $)$ & 0.68 & 1.76 & 0.62 & 4.84 & 1.99 \\
Gradient change $(-2 \%$ absolute $)$ & 0.86 & 1.55 & 0.55 & 4.73 & 1.58 \\
Gradient change $(+2 \%$ absolute $)$ & 0.83 & 1.69 & 0.56 & 3.30 & 1.85 \\
Wavelength $(-5 \mathrm{~nm})$ & 0.86 & 1.60 & 0.56 & 5.21 & 0.15 \\
Wavelength $(+5 \mathrm{~nm})$ & 0.86 & 1.60 & 0.56 & 5.24 & 0.35 \\
\hline
\end{tabular}

TABLE VI - Assay of pantoprazole and its main impurities in pharmaceuticals

\begin{tabular}{lcccc}
\hline \multirow{2}{*}{ Formulation } & \multicolumn{4}{c}{ Amount, $\% \pm$ SD } \\
\cline { 2 - 5 } & PNT & Impurity-A & Impurity-B & Impurity-C \\
\hline Pantosec 40 (tablet) & $99.04 \pm 0.98$ & $0.094 \pm 0.58$ & $0.021 \pm 0.93$ & $0.11 \pm 0.83$ \\
Allpan 40 (tablet) & $101.23 \pm 1.81$ & $0.075 \pm 0.61$ & $0.072 \pm 1.09$ & $0.089 \pm 0.41$ \\
Altopan- i.v. (injection) & $98.34 \pm 2.30$ & $0.092 \pm 0.33$ & $0.088 \pm 0.34$ & $0.061 \pm 1.02$ \\
\hline
\end{tabular}




\section{CONCLUSION}

The proposed stability indicating reversed-phase, gradient HPLC method on Shimadzu Hypersil ODS column have been developed and validated. The concomitant quantitation provides significant decrease in sample preparation, elution time, solvent and drug waste over the separation methods of analysis. Moreover, the specificity procedure and forced degradation studies revealed that the potential impurities i.e. Impurity A, Impurity B, Impurity $\mathrm{C}$ do not interfere with the determination of pantoprazole in the bulk and pharmaceutical formulations. The proposed HPLC method is simple, accurate, precise, specific, rugged according to ICH guidelines.

\section{REFERENCES}

AGBABA, D.; NOVOVI, D.; RAJI-KARLJIKOVI, K.; MARINKOVI, V. Densitometric determination of omeprazole, pantoprazole, and their impurities in pharmaceuticals. J. Planar Chromatogr-Mod. TLC, v.17, p.169-172, 2004.

CASTRO, S.L.; NETO, O.D.P.; SANTOS, S.R.B.; MEDEIROS, E.P. LIMA, R.A.C.; MARTINS, V.L.; ARAUEO, M.C.U.; SANTOS, J.C.C.; KORN, M. A Flow-injection biamperometric method for determination of pantoprazole in pharmaceutical tablets. J. AOAC Int., v.88, p.1064-1068, 2005.

DAN, W.R.; KEVIN, L.F.; JUNE, F.M.; KAREN, M.A.; TODD, D.H.; MICHAEL, G.M. Available guidance and best practices for conducting forced degradation studies. Pharm. Technol. Feb., v.48, p.48-56, 2002.

ERK, N. Differential pulse anodic voltammetric determination of pantoprazole in pharmaceutical dosage forms and human plasma using glassy carbon electrode. Anal. Biochem., v.323, p.48-53, 2003.

EUROPEAN PHARMACOPOEIA. Council of Europe. Strasbourg, 2008. p.3518-3519.

GOSAVI, S.A.; SHIRKHEDKAR, A.A.; JAISWAL, Y.S.; SURANA, S.J. A simple and sensitive HPTLC method for quantitative analysis of pantoprazole sodium sesquihydrate in tablets. J. Planar Chromatogr.-Mod. TLC, v.19, p.228$232,2006$.
GOSAVI, S.A.; SHIRKHEDKAR, A.A.; JAISWAL, Y.S.; SURANA, S.J. Quantitative planar chromatographic analysis of pantoprazole sodium sesquihydrate and domperidone in tablets. J. Planar Chromatogr.-Mod. TLC, v.19, p.302-306, 2006.

INTERNATIONAL CONFERENCE ON HARMONIZATION. ICH. Validation of analytical procedures: text and methodology Q2 (R1). Available at: <www.ich.org/ fileadmin/Public.../ICH.../Q2_R1/.../Q2_R1>. Accessed on: 23 nov. 2011.

JELENA, L.; SLAVKO, M.; JELENA, Z. High-performance liquid chromatographic determination of Pantoprazole and its main impurities in pharmaceuticals. J. AOAC Int., v.4, p.1121-1128, 2010.

JING, Y.M.; BEI, B.Y.; Xi, C.; SHAO, F.F.; SONG, W.; YAN, W.; MU, Z.W. Determination of Pantoprazole Sodium and Its Three Impurities by HPLC-DAD-MS. Chin. Pharm. J., v.45, p.1312-1315, 2010.

KOHL, B.; STURM, E.; RAINER, G. Dialkoxypyridines, process for their preparation, their use and medicines containing them. US 4,758,579, EP 166287.

KOHL, B.; STURM, E.; SENN-BILFINGER, J.; SIMON, W.A.; KRUGER, U.; SCHAEFER, H.; RAINER, G.; FIGALA, V.; KLEMM, K. $\left(\mathrm{H}^{+}, \mathrm{K}^{+}\right)$-ATP ase inhibiting 2-[(2-pyridylmethyl)sulfinyl]benzimidazoles.4. A novel series of dimethoxypyridyl-substituted inhibitors with enhanced selectivity. The selection of pantoprazole as a clinical candidate. J. Med. Chem., v.35, n.6, p.1049-1057, 1992.

KORMER, W.; KOHL, B. Pantoprazole sodium. Drugs Future, v.15, p.801-804, 1990.

LARSSON, H.; CARLSSON, E.; JUNGGREN, U.; OLBE, L.; SJOSTRAND, S.E.; SKANBERG, I.; SUNDELL, G. Inhibition of gastric acid secretion by omeprazole in the dog and rat. Gastroenterology, v.85, p.900-907, 1983.

MANSOUR, A.M.; SOROUR, O.M. High-performance liquid chromatographic determination of pantoprazole in tablet dosage form. Chromatographia, v.53, p.S478-S479, 2003. 
MARGUES, F.D.; VIANNA-SOARES, C.D.; NUNAN, E.; MOREIRA, C.; LIGIA, M. A Fast, validated HPLC method applied to the dissolution test of gastro-resistant capsules of pantoprazole pellets. J. Liq. Chromatogr. Related Technol., v.30, p.1833-1843, 2007.

MATHAD, V.T.; GOVINDAN, S.; KOLLA, N.K.; MADDIAPATLA, M.; SAJJA, E.; SUNDARAM, V. An improved and single-pot process for the production of pantoprazole substantially free from sulfone impurity. Org. Process Res. Dev., v.8, p.266-270, 2004.

MOUSTAFA, A.A.M. Spectrophotometric methods for the determination of lansoprazole and pantoprazole sodium sesquihydrate. J. Pharm. Biomed. Anal., v.22, p.45-48, 2000 .

NANDURI, V.V.S.S.; RAMAN, KURA, R.R.; ADAPA V.S.S.P.; KARIPEDDI, R. Validated Chromatographic Methods for the Determination of Process Related Toxic Impurities in Pantoprazole Sodium. Chromatographia, v.68, p.481-484, 2008.

PATEL, B.H.; SUHAGIA, B.N.; PATEL, M.M.; PATEL J.R. Determination of pantoprazole, rabeprazole,esomeprazole, domperidon and itopride in pharmaceutical product by reversed phase liquid chromatography using single mobile phase. Chromatographia, v.65, p.743-748, 2007.

PATEL, B.H.; SUHAGIA, B.N.; PATEL, M.M.; PATEL, J.R. Simultaneous estimation of pantoprazole and domperidone in pure powder and a pharmaceutical formulation by highperfomance liquid chromatography and high-performance thin-layer chromatography methods. J. AOAC Int., v.90, p.142-146, 2007.

RADI, A. Determination of pantoprazole by adsorptive stripping voltammetry at carbon paste electrode. Farmaco., v.58, p.535-539, 2003.

RADI, A. Square-wave adsorptive cathodic stripping voltammetry of pantoprazole. J. Pharm. Biomed. Anal., v.33, p.687-692, 2003.

RAHMAN, N.; BANO, Z.; AZMI, S.N.H. Kinetic spectrophotometric analysis of pantoprazole in commercial dosage forms. Anal. Sci., v.22, p.983-988, 2006.
RAHMAN, N.; KASHIF, M. Initial-rate method for the determination of pantoprazole in pharmaceutical formulations using 1-fluoro 2,4-dinitrobenzene. Pharmazie., v.60, p.197-200, 2005.

RAJIC, K.K.; NOVOVI, D.; MARINKOVI, V.; AGBABA, D. First-order UV-derivative spectrophotometry in the analysis of omeprazole and pantoprazole sodium salt and corresponding impurities. J. Pharm. Biomed. Anal., v.32, p.1019-1027, 2003.

REDDY, V.R.; RAJMOHAN, M.A.; SHILPA, R.L.; RAUT, D.M.; NAVEENKUMAR, K.; SURYANARAYANA, M.V.; MATHAD, V.T. A novel quantification method of pantaprazole sodium monohydrate in sesquihydrate by thermogravimetric analyzer. J. Pharm. Biomed. Anal., v.43, p.1836-1841, 2007.

SALAMA, F.; EL-ABASAWAY, N.; ABDEL-RAZEQ, S.A.; ISMAIL, M.M.F.; FOUAD, M.M. Validation of the spectrophotometric determination of omeprazole and pantoprazole sodium via their metal chelates. J. Pharm. Biomed. Anal., v.33, p.411-421, 2003.

SIVAKUMAR, T.; MANAVALAN, R.; MURALIDHARAN, C.; VALLIAPPAN, K. Multi-criteria decision making approach and experimental design as chemometric tools to optimize HPLC separation of domperidone and pantoprazole. $J$. Pharm. Biomed. Anal., v.43, p.1842-1848, 2007.

SIVAKUMAR, T.; MANAVALAN, R.; VALLIAPPAN, K. Development and validation of a reversed-phase HPLC method For simultaneous determination Of domperidone and pantoprazole in pharmaceutical dosage form. Acta Chromatogr., v.18, p.130-142, 2007.

SIVAKUMAR, T.; RAJAPPAN, M.; KANNAPPAN, V. Stability-Indicating HPLC Method for Simultaneous Determination of Pantoprazole and Domperidone from their Combination Drug Product. Chromatographia, v.67, p.41-47, 2008.

STORMS, M.L.; STEWART, J.T. Development of a reversedphase liquid chromatographic method for the analysis of amoxicillin, metronidazole and pantoprazole in human plasma using solid-phase extraction. J. Liq. Chromatogr. Relat. Technol., v.25, p.2433-2443, 2002. 
TIVESTEN, A.; FOLESTAD, S.; SCHONBACHER, V.; SVENSSON, K.; Nonaqueous capillary electrophoresis for the analysis of labile pharmaceutical compounds. Chromatographia, v.49, p.S7-S11, 1999.

WAHBI, A.A.M.; ABDEL-RAZAK, O.; GAZY, A.A.; MOHGOUB, H.; MONEEB, M.S. Spectrophotometric determination of omeprazole, lansoprazole and pantoprazole in pharmaceutical formulations. J. Pharm. Biomed. Anal., v.30, p.1133-1142, 2002.
WALLMARK, B.; LORENZO, P.; LARSSON, H. The relationship between gastric $\mathrm{H}^{+} \mathrm{K}^{+} \mathrm{ATP}_{\text {ase }}$ activity. J. Biol. Chem., v.260, p.13681-13685, 1985.

ZEINAB, A.E.S.; AFAF, O.M.; MOHAMED, G.E.B.; MOHAMED, F.E.T. Reversed-phase high performance liquid chromatographic method for the determination of lansoprazole, omeprazole and pantoprazole sodium sesquihydrate in presence of their acid-induced degradation products. Chem. Pharm. Bull., v.54, p.814-818, 2006.

Received for publication on $28^{\text {th }}$ November 2011 Accepted for publication on $26^{\text {th }}$ October 2012 